\title{
DEPOLITIZÁCIÓ ÉS POLITIZÁCIÓ A PAKSI BŐVÍTÉS DELIBERÁCIÓJÁBAN*
}

\author{
Egres Dorottya \\ (Budapesti Múszaki és Gazdaságtudományi Egyetem \\ Filozófia és Tudománytörténet Tanszék)
}

A tanulmány beérkezett: 2020. március 15., opponálás: 2020. március 16. - 2020. április 2., véglegesítve: 2020. június 20.

\begin{abstract}
ÖSSZEFOGLALÓ
A paksi atomerőmú bővítéséről 2014-ben született meg az egyezmény Magyarország és az Orosz Föderáció között, mely szerint a két új reaktort az orosz állami vállalat, a Roszatom fogja biztosítani, és 3000 milliárd forint értékủ államközi hitel fogja finanszírozni a beruházás 80 százalékát. Tanulmányomban a bővítésről szóló deliberáció 2014 és 2017 közötti szakaszának makroszintû diszkurzív vizsgálatát végzem el. Bemutatom, hogy a Paks 2-ről szóló döntés legitimitása három szempontból kérdőjeleződött meg: a döntést tender nélkül és a parlamenti vitát megelőzően hozták meg, a döntést alátámasztó dokumentációt titkosították, valamint a társadalmat kihagyták a döntéshozatali folyamatból. Ezekről a pontokról szóló érveket vizsgálom Magyarország Kormánya és az LMP hivatalos honlapjainak cikkeiben, majd az érveket depolitizációs és politizációs kísérletekként értelmezem.
\end{abstract}

Kulcsszavak: politikai deliberáció depolitizáció @érvelés a atomenergia

\section{BEVEZETÉS}

A nukleáris energia magyarországi diskurzusán „médiaviharként” (SzabóBene, 2016: 40.) söpört végig a hír 2014 januárjában a Magyarország és az Orosz Föderáció kormányközi megállapodásáról, amely magában foglalta a paksi atomerőmű két új reaktorral történő bővítését a Roszatom orosz állami vállalat által. A bővítésre az orosz állam 3000 milliárd forint értékű hitelkeretet bocsátott rendelkezésre, mely hozzávetőlegesen a beruházás 80 százalékát teszi ki. A megállapodást közbeszerzési eljárás nélkül, azelőtt írták alá a felek, hogy a

\footnotetext{
* A tanulmány a COST Action CA17132 - APPLY European Network for Argumentation and Public Policy Analysis támogatásával készült. A COST APPLY érveléselméleti és közpolitikai kérdésekben történő nyilvános döntéshozatali folyamatokat elemző európai hálózat.
} 
kabinettel, illetve az Országgyúléssel megvitatták volna. Az Oroszországgal kötött 2014-es egyezmény kétségkívül megosztóvá tette az atomenergia kérdését hazánkban. Ennek oka többek között Magyarország múltja, Oroszország világpolitikai megítélése, az új atomreaktorokra vonatkozó tender kiírásának elmaradása, a rendkívüli nagy összegú hitel, valamint az, hogy a Pakson jelenleg múködő négy reaktor a Szovjetunió közbenjárásával épült. Mi sem mutatja jobban az Oroszországgal kötött megállapodás ellentmondásosságát, mint az, hogy a Greenpeace által, 2014 után megrendelt felmérések egyike sem az atomenergia támogatottságára kérdezett már rá, hanem az atomerőmú orosz állami vállalat, orosz hitelből történő bővítésére. ${ }^{1}$

A hasonlóan nagy horderejű döntések hatására jellemzően aktivizálódik a vitatér, amelynek ezesetben már nem az atomenergia kérdése, hanem az Oroszország közbenjárásávál épülő Paks 2 a tárgya. A nukleáris energia nagyjából 40 százalékos részarányának fenntartását a hazai energiatermelésben egyesek szakmai, illetve szakpolitikai kérdésnek minősítik, mások pedig a kérdés politikai és társadalmi aspektusát hangsúlyozzák. Ebből következően felmerül a kérdés, hogy ki vehet részt a döntéshozatali folyamatban, valamint ki képes megalapozottan döntést hozni. A megalapozott döntéshozatal előfeltételének pedig a döntéshez szükséges információkhoz való hozzáférés tekinthető. Jelen tanulmány a paksi atomerőmü bővítéséről szóló deliberáció 2014 és 2017 közötti szakaszának argumentatív vizsgálatát adja. 2017-ben zárta le ugyanis az Európai Bizottság az új atomerőmúvi blokkok létesítésére irányuló magyarorosz kormányközi megállapodással kapcsolatos vizsgálatát, amivel a jogi akadályok elhárultak a projekt kivitelezésének megkezdése elől. A tanulmány két kutatási kérdése a következő: Hogyan érvel Magyarország Kormánya mint a bővítés elsőszámú politikai támogatója és a Lehet Más a Politika mint a bővítést ellenző zöld párt a tender és előzetes vita nélkül megkötött megállapodás, a bővítés dokumentációjának titkosítása, valamint a társadalom döntéshozatalban való részvétele és támogatása kapcsán? Hogyan következik az azonosított érvekből Paks 2 kérdésének depolitizációja és politizációja a különböző hatalmi pozíciókban lévő politikai szereplők esetében?

A tanulmány először ismerteti az elméleti keretként alkalmazott deliberáció, depolitizáció és politizáció koncepcióit. A deliberációra olyan makro szintû folyamatként tekintek, amelyben a racionális mérlegelés mellett a meggyőzés is szerepet játszik. A depolitizációs kísérletek a vita és a felelősségre vonhatóság elkerülésére irányulnak (Burnham, 2001; Kettell, 2008). A depolitizáció során megfogalmazódik az eset szakmai kérdésként történő értelmezése, aminek következtében a szakértőkre szúkül a döntésben érintettek köre, ugyanis kizárólag ők képesek kellő hozzáértéssel mérlegelni a rendelkezésre álló opciókat. A politizáció azt jelenti, hogy az esetet olyan politikai és társadalmi kérdésnek állítják be, amelyben a társadalomnak szélesebb körben is legitim 
megnyilatkozni (Ylönen et al., 2015). A depolitizációs és a politizáció egymással dialektikai viszonyban állnak, miként az az eltérő hatalmi pozíciókban lévők tevékenységére jellemző (Strange, 2014; Tafon et al., 2018). Érdekes módon Paks 2 szakmai vagy társadalmi kérdésként való meghatározása, valamint a döntésben megnyilatkozók körének dilemmája nem kizárólag a politikai szférában merült fel, a mérnöki és a társadalomtudományos diszciplínák kutatóit egyaránt megosztja a kérdés. ${ }^{2}$

Az elméleti keret felvázolását követő részben a jelen tanulmány kutatási előzményeit és az alkalmazott módszertant ismeretem. Magyarország Kormányának és a Lehet Más a Politika hivatalos honlapján, a bővítés témájában 2014 és 2017 között megjelent cikkeket elemzem. Az állami szerv és a politikai párt cikkeiben a Paks 2 mellett és ellen szóló érvek a döntés legitimitásának három kritériuma szempontjából kerülnek azonosításra: a tender és előzetes politikai vita nélkül kötött kormányközi megállapodás, a döntés alapját képező dokumentáció titkosítása, valamint a döntés által érintettek megnyilatkozásának lehetôsége. Az állami szerv és az ellenzéki zöld párt monologikus érvelése dialektikai viszonyba állítható, ahogy megmutatják, ezen három kritériuma kérdőjeleződött meg a Paks 2-ről szóló döntés legitimitásának. A 2014-es kormányközi megállapodást a felek közbeszerzési eljárás nélkül és az országgyúlési vitát megelőzően kötötték meg. A paksi szerződéseket ezt követően titkosították, melyek politikai és civil szervezetek bírósági pereinek hatására kerültek nyilvánosságra évek múltán. Mindeközben az ellenzéki pártok népszavazási kezdeményezésekkel próbálták megakadályozni a projektet. A kormány érvelése e három tekintetben depolitizációs kísérletre enged következtetni, míg a zöld párt érvelése politizációra.

Ylönen és szerzőtársai (2015) a depolitizáció és a politizáció kísérleteit a fukusimai atomkatasztrófát követően vizsgálták a nukleáris energiáról folytatott finnországi diskurzusokban. Jelen írás azt hivatott megerősíteni, hogy a depolitizációs és a politizációs kísérletek nemcsak egy atomkatasztrófa után jellemzik a különböző hatalmi pozíciókban lévők tevékenységét, hanem a vita szereplői egy olyan politikailag számottevő döntés hatására is alkalmazzák azokat, mint az új paksi atomreaktoroknak az orosz állami vállalat által történő szállítása és az orosz állami hitelfelvétel. Tehát a vita sarkalatos pontja a magyarországi kontextusban egy politikailag megosztó esemény, nem pedig egy elsősorban biztonságtechnikai szempontból releváns eset. Tanulmányom továbbá egy létező deliberatív folyamat kontextuális vizsgálatával kíván hozzájárulni az érveléselmélet és a politikatudomány diszciplínáinak azon közös törekvéséhez, amit „kontextuális fordulatnak” neveznek. Ennek értelmében a deliberáció normatív feltételeinek felállítása helyett a valós deliberatív kontextusok leírása a cél (Lewiński-Mohammed, 2013), melynek eszköze a depolitizáció és politizáció elemzése az energiapolitika területén. 


\section{DELIBERÁCIÓ, DEPOLITIZÁCIÓ ÉS POLITIZÁCIÓ}

Az argumentációelmélet és a politikatudomány diszciplínáiban egyaránt fontos kiindulópontnak tekinthető a deliberáció koncepciója, amely egészen Arisztotelészhez vezethető vissza. Az arisztotelészi értelmezés szerint (1997) a deliberáció a döntést megelőző ítéletalkotás folyamata, amelyben az egyén mérlegeli a lehetőségeket, majd leteszi a voksát az egyik lehetőség mellett. Az utóbbi három évszázadban a deliberáció elméletében egyre nagyobb szerepet kapott a demokratikus, politikai, nyilvános és kollektív deliberáció vizsgálata. A koncepció iránti érdeklődés a politikatudomány területén annak változatos definícióit eredményezte, ennek következtében az érveken alapuló döntéselőkészítés demokratikusságának vizsgálata megannyi formális és informális folyamatra kiterjedt (Myers-Mendelberg, 2013; Parkinson, 2006; CarpiniCook-Jacobs, 2004). Megállapítható, hogy mára „a deliberáció meglehetősen képlékeny fogalommá vált" (Vépy-Schlemmer, 2015: 36.). A politikatudományban széles körben vitatott skála problémája (Parkinson, 2006; Boniolo-Schiavone, 2015) rámutat arra, hogy többféle politikai döntéshozatali (és érvelési) folyamat is deliberációnak tekinthető.

Számos kutatás úgy tekint a deliberációra, mint egy kiscsoportos döntéshozatali folyamatra és az érvelések szigorú eljárások szerinti előadására (Elster, 1998; Cohen, 1989; Gutmann-Thompson, 1996; 2004). Egyesek a deliberatív elveket az állampolgári tanácsok (Stewart-Kendall-Coote, 1994; Smith-Wales, 2000), a deliberatív közvélemény-kutatások (Fishkin, 1997), a konszenzus konferenciák (Joss-Durant, 1995) és a parlamenti viták (Bessette, 1994) keretében kutatják. Hasonló döntéshozatali folyamatnak tekinthető a paksi bővítés esetében a Nemzeti Energiastratégiában levezetett forgatókönyvek megalkotása, amelyek magát a Paks 2-ről szóló döntést készítették elő. A kiscsoportos deliberációk szakirodalma ugyanakkor arról számol be, hogy 5-7 fővel érhető el az optimális döntéshozatali folyamat, amely létszámnál ugyanis a résztvevők ismerhetik egymást, és tudnak egymásra reagálni (Fisher-Ellis, 1993). Goodin szerint (2000: 83.) relatíve kis létszám fölött a résztvevők tevékenysége már nem nevezhető deliberációnak, ahogyan a dialógust felváltják a monologikus szövegek, az észérveket pedig a retorikai eszközök. Tehát megkérdőjelezhető, hogy az olyan sokszereplős folyamatok, mint egy több száz fővel megrendezett közmeghallgatás a paksi régióban vagy akár egy parlamenti vita, leírhatók-e deliberációként (Parkinson, 2001).

A makroszintû́ megközelítés szerint (Parkinson, 2006) a deliberáció időben és térben nem lokalizálható, ahogyan a deliberatív tevékenységek eltérő helyszíneken és időpontokban, különböző személyek részvételével zajlanak, továbbá a résztvevőket általában csoportosítani lehet beszélő, közönség és döntéshozó szerint. A deliberáció tehát ebben az értelmezésben decentralizált. Ezt a felfogást tükrözi Mansbridge elmélete a deliberatív rendszerekről (1999), 
amelynek részét képezik formális és reprezentatív struktúrák, de az informális közszféra és a magánbeszélgetések is politikaiként jellemezhetők. A diszkussziók egy formális-informális skála mentén képzelhetők el, melyek kimenetelei a skála informális végpontja felé közelítve egyre kevésbé tekinthetôk kötelező érvényûnek. Mansbridge (2010) továbbá megfogalmazza, hogy bizonyos jelzőkkel ellátva különböztethetők meg a deliberáció egyes formái. A kötelező érvényű döntéseket meghozó fórumokat felhatalmazottként (empowered) nevezi meg, amely elkülönül a tanácskozó (consultative) és a közösségi (public) deliberációtól (a jelzők magyar fordításait illetően lásd Vépy-Schlemmer, 2015). Eszerint tehát elkülöníthető például a felhatalmazott parlamenti deliberáció az országgyưlési képviselők részvételével, amely 2014-ben a kormányközi egyezmény aláírásától február 6-ig tartott, a tanácskozó deliberáció, amely során a paksi régióban tartottak közmeghallgatásokat, illetve a közösségi deliberáció, úgy, mint politikusok médiavitája. Parkinson szintén kiemeli (2006), hogy a demokratikus értelemben vett deliberáció magában foglalja a döntéshozatali folyamat minden részét a probléma megfogalmazásától, a lehetséges megoldások diszkusszióján keresztül a döntés meghozataláig és annak implementációjáig. Ennek értelmében tehát a kormány, és az LMP saját honlapján történő érvelések is deliberációnak tekinthetők.

A deliberációt az érvelés irányítja az alkudozás és az egyéni preferenciák aggregációjával szemben, valamint az érvek mérlegelése, elfogadása, kritikája egy nyilvános folyamat a titkos szavazással szemben (Parkinson, 2006). Ugyanakkor a valós kontextusokban lejátszódó deliberációk nem írhatók le tisztán racionális folyamatként. A politikatudományban is megjelenik a gondolat, miszerint a deliberáció nem kizárólag az érvek felfedezésének, hanem egymás meggyőzésének is a folyamata (Manin-Stein-Mansbridge, 1987), ez az argumentációelméletben viszont annál nagyobb hangsúlyt kap. Walton a deliberációt az egyik leggyakoribb dialógustípusként írja le (1998), amelynek során érvelések formájában diskurzus zajlik a dialóguspartnerrel arról, hogyan cselekedjenek adott körülmények között egy cél elérése érdekében. A résztvevőknek közös a céljuk, és eszközöket próbálnak keresni a cél elérése érdekében, tehát a szituáció határozottan kooperatív jellegú. Walton ugyanakkor belátja, hogy a politikai döntéshozatalt és vitát nemcsak ez ilyesféle folyamat jellemzi, hanem egyaránt megjelennek benne a meggyőzési dialógus jellegzetességei. Az érveléselmélet jelenleg is meghatározó iskolájában is kutatott a deliberáció koncepciója (van Eemeren, 2010 és 2018). A pragma-dialektika és annak kiterjesztett elmélete, a stratégiai manőverezés szerint a politika területén belül a kommunikációs tevékenységek nagy része a deliberáció müfajába sorolható. Egyazon területhez tartozó és egyazon müfajba sorolható kommunikációs tevékenységek osztoznak a közös intézményi célokon, amely a politika területén belül a demokratikus politikai kultúra fenntartása. Van Eemeren a deliberációt tágan értelmezi, hasonlóan Mansbridge-hez (1999), tehát egy- 
aránt beletartoznak a formális intézményes gyakorlatok és az egyéb informális tevékenységek. A pragma-dialektika szerint a deliberáció múfajába határozottan argumentatív kommunikációs tevékenységtípusok sorolhatók. A közönség részvétele kiemelkedő jelentőségü, ugyanis a politikában a vitázók aligha egymást akarják meggyőzni, hanem a szavazókból álló közönség támogatását szeretnék elnyerni.

A deliberációhoz hasonlóan a depolitizáció koncepciójáról is változatos értelmezések születtek. A sokféle elméleti keret és konceptualizáció, a módszertani sokszínúség ellenére a depolitizáció fogalma a kormányzás mai formáinak megértésére az egyik legalkalmasabb (Foster et al., 2014: 226.). Általánosságban véve a depolitizáció fogalma azokat a stratégiákat, taktikákat, eszközöket takarja, amelyek alkalmazásának célja a felelősségre vonhatóság és a vita elkerülése (Burnham, 2001; Kettell, 2008). Wood és Fliners (2014: 65.) egyszerre tekint a depolitizációra (és a politizációra) mint kormányzati, társadalmi és diszkurzív stratégiára (Antal, 2016). Wood (2016: 4.) továbbá a retorikai stratégiára helyezi a hangsúlyt a kormányzat államvezetési stratégiája helyett (Antal, 2016). A továbbiakban a depolitizáció mint stratégia makroszintű diszkurzív elemzését végzem el (Flinders-Buller, 2006; Wood-Flinders, 2014). A depolitizáció tetten érhető diszkurzív manőverekben (Bates et al., 2014; Jenkins, 2011), amelyekkel a hatalmi pozíciókban lévők alakítják közönségeik preferenciáit, és egyben korlátozzák a rendelkezésükre álló lehetőségeket. A depolitizáció ebben a diszkurzív értelmezésben tehát nem a vita kiiktatására vagy lezárására irányuló állami vagy jogi intézkedéseket takarja, hanem retorikai megnyilvánulásokat, amelyek egy makroszintû stratégia részeként foghatók fel. A depolitizáció során a szakértőkre szúkül a döntésben érintettek köre, ugyanis kizárólag ők képesek kellő hozzáértéssel mérlegelni a rendelkezésre álló opciókat (Ylönen et al., 2015). A politizáció stratégiájában az ügy vitathatóságára irányítják a figyelmet, valamint az esetet olyan politikai és társadalmi kérdésnek állítják be, amelyben a társadalomnak szélesebb körben is legitim megnyilatkozni. A depolitizáció dialektikai viszonyban áll a politizációval (Strange, 2014; Tafon et al., 2018), a két stratégia mint egymásra adott reakciók értelmezhetők. A depolitizáció az energiapolitika területén is vizsgálható. Kuzemko (2015) az Egyesült Királyság energiagazdálkodása, Tafon és szerzőtársai (2018) Észtország offshore (tengerre kihelyezett) szélerőművei, Bond és szerzőtársai (2018) az új-zélandi mélytengeri olajfúrás és -kitermelés, Chailleux (2020) Franciaországban a palagáz kinyerésére szolgáló hidraulikus repesztéses technológia, illetve Polleri (2019) a fukusimai atomkatasztrófa utáni radioaktivitás kapcsán vizsgálták a depolitizációs stratégiákat. 


\section{KUTATÁSI ELŐZMÉNYEK, MÓDSZERTAN}

Jelen tanulmány annak a kutatásnak a folytatása, amelynek keretében 2017 óta foglalkozom az atomenergia magyarországi diskurzusának elemzésével. Kutatásom a paksi bővítésről szóló vita politikai, környezetvédelmi és szakértő szervezetek honlapjának elemzésével kezdődött (Egres-Petschner, 2020). Bizonyos politikai, környezetvédő és szakértői szervezetek hivatalos honlapján, a 2009 és 2017 közötti, az atomenergia és Paks 2 témájában megjelent cikkek kerültek elemzésre, amelynek során egyértelmúvé vált, hogy a szövegekben Paks 2 mellett és ellen szóló, azonosítható érvek ismétlődnek és ezek tipizálhatók. A kiinduló kutatási kérdések a következők voltak: milyen témakörökbe sorolhatók a politikai, környezetvédelmi és szakértői honlapok cikkeiben azonosítható leggyakoribb érvek, valamint melyik témakörbe mennyi érv sorolható? Argumentatív elemzésünk alapegysége az érv volt, melynek definíciója egy állítás, ami megalapozza egy-egy elemzett szereplő konklúzióját a vitában (legyen vagy ne legyen Paks 2). Az érvek témaköreiként a következők kerültek megállapításra: gazdaság, pénzügy, politika, jog, etika, energiaellátás, biztonság, környezet (1. ábra). Mind a nyolc témakörön belül megnevezésre kerültek a leggyakoribb érvek. A korábbi kutatásnak jelenleg is fut egy argumentációelméleti vonala, amely a társadalom információigényének és preferenciáinak irányából vizsgálja az imént felsorolt szervezetek érvelését (Egres, megjelenés alatt).

1. ábra. a témakörökbe sorolt érvek száma az egyes szereplőknél ${ }^{3}$

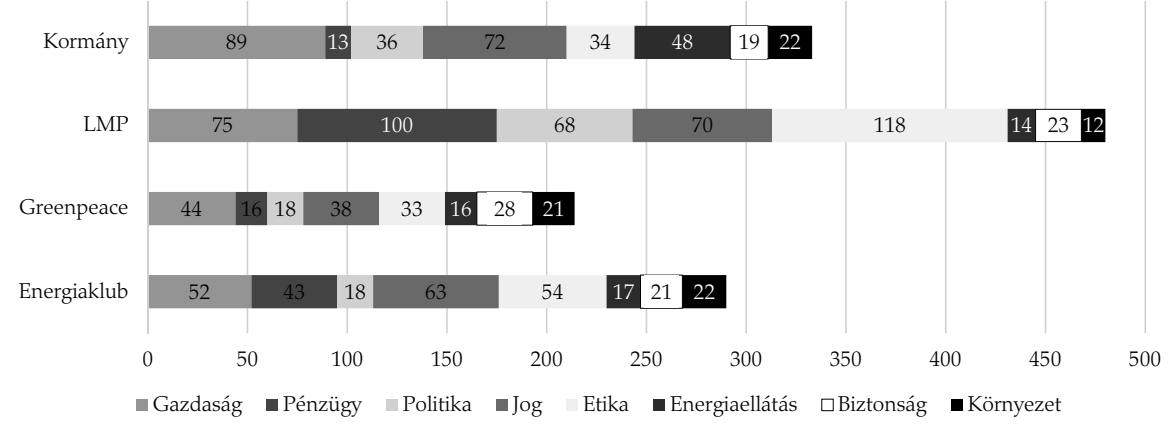

Jelen tanulmányban az argumentációelméleti megközelítés mellett politikatudományi vizsgálati szempontok kerülnek előtérbe, ahogyan az érvek témaköreit a döntés legitimitásának kritériumaival kapcsolom össze, illetve depolitizációs és politizációs kísérletként tekintek egyes diszkurzív manőverekre. A paksi bővítésről szóló vitának kizárólag a 2014-től kezdődő szakaszára fókuszálok, az Orosz Föderációval megkötött megállapodás utáni időszakra, ugyanis ez az 
esemény határozta meg, hogy a nukleáris energia hosszú távú megtartása a hazai energiamixben milyen konstrukcióban történik. A négy szereplő (1. ábra) közül a továbbiakban Magyarország Kormánya és a Lehet Más a Politika érvelésére fókuszálok. Ennek oka, hogy a korábban vizsgált szereplők közül a kormány az egyetlen támogatója a projektnek, az LMP pedig egyrészt mint zöld politikai párt ellenzője a bővítésnek, másrészt ez a párt rendszeresen és részletesen kommunikál az atomenergia témájában. A választás azért esett a szervezetek saját hivatalos honlapjára, ${ }^{4}$ mert az ezeken megjelenő írások tudatosan megalkotott kommunikációs anyagoknak tekinthetők, amelyek az állami szerv és az ellenzéki párt hivatalos álláspontját közvetítik. Annak ellenére, hogy a honlapokon megjelenő cikkek monologikus szövegek, az argumentatív vizsgálat rámutat arra, hogy a bennük azonosított érvek egymással dialektikai viszonyban értelmezhetők. A monológusokból felépülő deliberációra az argumentációelmélet implicit diszkusszióként tekint (van Eemeren-Houtlosser, 2002; Walton-Krabbe, 1995), a politikatudományban pedig megjelenik a gondolat a deliberáció kapcsán, miszerint nyilvános dialógus még úgy is lehetséges, ha a másik fél nincs fizikailag jelen (Bohman, 1996: 24.).

A bővítés diskurzusában azonosított témakörök (1. ábra) közül jelen tanulmányban kizárólag a jogra és az etikára fókuszálok. A jog témakörébe kerültek besorolásra azok az érvek, amelyek a projekt magyar, illetve nemzetközi és Európai Uniós jogszabályoknak való megfeleléséról szólnak. Az etika témakörébe pedig azok az érvek kerültek besorolásra, amelyek a társadalom döntéshozatalban való részvételét, a projekt társadalom általi támogatottságát, a politikai és a szakmai viták adekvátságát, valamint a jövő generációkra kifejtett hatását taglalják. ${ }^{5}$ A kormány azzal érvel, hogy Paks 2 nem ütközik egyetlen jogszabályba sem, a társadalom a megfelelő mértékben és módon részt vett a döntéshozatalban, illetve támogatja is a projektet, politikai vitákra megfelelően sor került. Az LMP azzal érvel, hogy a projektet a felmerülő jogi aggályok miatt be kell szüntetni, a társadalmat kihagyták a döntéshozatalból, a társadalom többsége nem is támogatja Paks 2-t, politikai vitákra nem került sor megfelelő mértékben. A 2. ábra mutatja, hogy milyen számban azonosíthatók a kormány és az LMP 2014 és 2017 közötti online cikkeiben a jog és az etika témakörének különböző érvei. A két témakör összekapcsolható a deliberáció szakirodalmában megjelenő legitimitási kritériumokkal. A felek érvelésében megfigyelhető, hogy ezen kritériumok mentén kérdőjeleződött meg a Paks 2-ról szóló döntés legitimitása.

A politikatudomány a valós deliberatív kontextusokban született döntések legitimitását a normatív modellektől való eltérés alapján értékeli. Ahogy az elméleti keretet felvázoló részben említettem, számos normatív modell létezik, jelen tanulmányban viszont kizárólag a következő három kritériumra reflektálok: a döntést nem kizárólag egy szúk csoport hozza meg (Dryzek, 1996), az érvelések nyilvánosak (Parkinson, 2006), a döntés az általa érintettek véle- 
ménynyilvánítása és beleegyezése alapján születik (Dryzek, 2001; Bohman, 1996; Sanders, 1997). A következő három részben a kormány és az LMP érvelését részletesen és példákkal együtt mutatom be a döntés legitimitásának három imént említett kritériumához kapcsolódóan. Először a döntés meghozatalának kritériumával kapcsolatban tárgyalom a tender elmaradásáról és a parlamenti vita utólagosságáról szóló érveket. Ezek részben a jog témakörébe kerültek besorolásra, mert az Európai Unió vizsgálódott a közbeszerzési szabályok betartását illetően, részben pedig az etika témakörébe a politikai vita adekvátsága miatt. Másodszor az érvek nyilvánosságának kritériumával kapcsolatban elemzem az adatok nyilvánosságáról szóló érveket, amelyek a titkosítás magyar jogi vonatkozása okán a jog témakörébe kerültek besorolása. Harmadszor a döntés által érintettek véleménynyilvánítási lehetőségével kapcsolatban vizsgálom a társadalom részvételéről és támogatásáról szóló érveket, ezek az etika témakörébe sorolhatók.

Miután a valós deliberatív helyzetek rendre elmaradnak a modellek által leírt ideáloktól, ezért a deliberáció adekvátságát érdemes egy skála mentén elképzelni (Fishkin, 1997). Nem egyértelmú ugyanis, hogy mennyi hiányosságnak kell megmutatkoznia, hogy ne is legyen deliberációként értékelhető egy folyamat. Elképzelhető, hogy egyesek szerint a döntés visszafordíthatatlan, mégis részt vesznek az utólagos deliberációban, hogy közvetett céljaikat próbálják beteljesíteni, úgymint a kormányváltás. Még akkor is, ha előzetesen nem történt deliberáció, az utólagos deliberáció segíthet a döntés elfogadásában, az elszámoltatásban, a jövőbeni döntések jobb meghozatalában (Gutmann-Thompson, 2004).

\section{A DÖNTÉS MEGHOZATALA}

A továbbiakban tehát a korábbi kutatásomban (Egres- Petschner, 2020) azonosított jog és etika témakör érveit fogom bemutatni a döntés legitimitásának három kritériuma mentén, továbbá értelmezem az érveket mint diszkurzív depolitizációs és politizációs kísérleteket. A bővítést támogató és ellenző oldal érvelési példáinak bemutatása és értelmezése során fontosnak tartom, hogy azokat dialektikai viszonyban kezeljem, ahogyan azok egymásra adott reakcióknak is tekinthetők.

2014 januárjában megszületett a magyar-orosz megállapodás az új atomerőmúvi blokkok kivitelezésérôl és finanszírozásáról. A magyar fél részéről Németh Lászlóné fejlesztési miniszter azonban azelőtt írta alá a szerződés, minthogy a döntés parlamenti vitájára sor került volna. Tehát egy olyan deliberatív szituációról van szó, amely nem a döntés meghozatala előtt, hanem utána történt meg. Az Országgyúlés február 6-án szavazta meg az atomenergetikai nemzetközi együttmúködésről szóló törvényjavaslatot. A kormány és az LMP érvelése két szempontból is szembekerül egymással: mennyiben szük- 
séges a politikusoknak vitázni a bővítés kérdésében, valamint jogsértő-e a közbeszerzési eljárás elmaradása (1. táblázat).

1. táblázat. Érvek a döntés meghozataláról

\section{Kormány}

Süli János miniszterjelölt szerint az atomerőmú bővítésének ügye fontosabb annál, semhogy viták hátráltassák. ${ }^{6}$

A Magyar Országgyuulés 2009-tôl kezdve mindegyik parlamenti ciklusban megerősítette, hogy egyetért a jelenlegi atomenergia-termelés részarányának hosszú távú fenntartásával. ${ }^{8}$

[...] a 2014-es parlamenti választás előtt az általános kormányközi szerződés, a választások után pedig a fejlesztés pénzügyi hátteréről szóló dokumentum vitájába kapcsolódhatott be minden parlamenti képviselő, szabadon kialakíthatták véleményüket, és meghozhatták döntésüket az ügyben. ${ }^{10}$

[...] a lehetőséget „minden országnak felkínáltuk", azzal a feltétellel, hogy az erőmúnek biztonságosnak kell lennie és állami tulajdonban kell maradnia, a beruházó partnernek pedig rendelkeznie kell a szükséges pénzügyi forrásokkal. Mindezt csak az oroszok tudták teljesíteni, „ezért ők nyertek". ${ }^{12}$

[...] a magyar kormány álláspontja, hogy joga van harmadik országgal államközi szerződést kötni az atomerőmú bővítésére az Euratom és a bizottság szabályainak betartásával. ${ }^{14}$

[...] az Európai Bizottság megszüntette azt a kötelezettségszegési ügyet, amit a paksi projekt közbeszerzési kérdésében indított, azt állapította meg, hogy megfelelően járt el a magyar kormány. ${ }^{16}$

\section{LMP}

[...] ma a házbizottságban minden tiltakozásunk ellenére az hangzott el, hogy időkeretben akarják ezt az egyezményt megtárgyalni. $^{7}$

[...] a kormány tegyen új előterjesztést a paksi erőmú bővítése ügyében az Országgyúlésnek, mivel álláspontja szerint a korábbi országgyưlési határozat nem volt kellóképp elókészítve. ${ }^{9}$

[...] a paksi titoktörvény megszavazása óta a Fidesz-KDNP politikusai rendre nem hajlandók a nyilvánosság előtt vitában megvédeni álláspontjukat. ${ }^{11}$

Tender helyett azóta Orbán-Putyin-paktum köttetett. ${ }^{13}$

[...] a Lehet Más a Politika (LMP) szerint nemzetközi szerződést sért a paksi atomerőmú bővítéséről megkötött magyar-orosz megállapodás. ${ }^{15}$

[...] azt mondta, az Orbán-Putyin megállapodás aláírása óta nyilvánvaló volt, hogy az orosz atomprojekt nem egyeztethető össze az uniós szabályokkal, sem a közbeszerzés elhagyása, sem a finanszírozás, sem a pénzügyi információk eltitkolása nem felel meg az EU-s jogrendnek. ${ }^{17}$ 
A kormány elsősorban a politikai vita szükségtelenségével érvel: egyrészt arra hivatkoznak, hogy a bővítés össznemzeti érdek, ezért nem szabad azt vitáknak hátráltatnia, másrészt a 2009 -es országgyúlési határozat ${ }^{18}$ az erőmü jövőbeni lehetséges bővítéséről már a projekt elfogadásának minősül. A 2014. február 6-i döntést megelőző vitát a kormány elegendőnek és megfelelőnek ítélte a kérdés elfogadására. A kormány érvelésére egyaránt jellemző, hogy a vitát szükségtelennek, ugyanakkor elégségesnek is nevezi. Az ilyen típusú érvekre depolitizációs kísérletekként lehet tekinteni, mert a depolitizáció a vita kiiktatására irányul (Burnham, 2001; Kettell, 2008). Ezzel szemben az LMP újabb politikai vitákat szorgalmaz, illetve felhívják a figyelmet a kormány vitát kerülő tevékenységére, ami politizációként értelmezhető. A politikai vita adekvátságára vonatkozó érvek az etika témakörébe sorolhatók, ugyanis nem jogi szabályokat sértenek, sokkal fontosabb ezeknek az ügyeknek az etikai jelentősége. A közbeszerzési eljárás elmaradása kapcsán a kormány azt állítja, hogy a tender hiányát az előzetes szakmai mérlegelések és egyeztetések magyarázzák, ugyanis Oroszországon kívül egyik ország sem lett volna képes a megfelelő specifikációkkal kivitelezni a projektet. Ezt a lépést az LMP politikai színben tünteti fel, azaz a technológiai és gazdasági indokok helyett politikai paktumot vél felfedezni a két ország között. Felmerül azonban, hogy a tender nélkül megkötött egyezmény jogsértő, amit az Európai Bizottság ki is vizsgált, de az eljárást 2016-ban megszüntette. A tender kérdése tehát a jog témaköréhez tartozik, azon belül is a nemzetközi és Európai Uniós törvények betartásához. A kormány érvelése ebben az esetben is depolitizációra enged következtetni, amikor jogi ügyként nevezik meg a kérdést, és a vitát azzal hárítják el, hogy a döntés az Európai Bizottság hatáskörébe tartozik. Az LMP tevékenységét arra összpontosítja, hogy felhívja a társadalom figyelmét a potenciális jogsértésre, illetve a jogi kérdés politikai aspektusára, amely pedig politizációt jelölhet.

2. ábra. Az érvek száma témakörönként

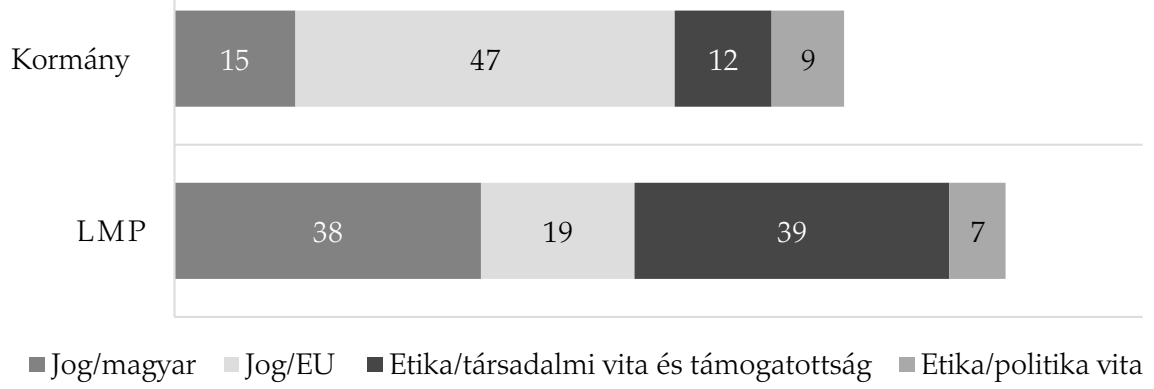


A 2. ábra mutatja, mennyi érv került azonosításra 2014 és 2017 között az állami szerv és az ellenzéki párt hivatalos honlapjainak Paks 2-ről szóló cikkeiben, az etika és a jog témakörén belül. A döntés meghozatalának módja kapcsán a szereplők érvelése azt mutatja, hogy a kormány jóval gyakrabban nyilatkozta, hogy a projekt nem ütközik Európai Uniós jogszabályokba, mint amilyen gyakran az LMP kritikát fogalmazott meg. A politikai vita adekvátságát illetően nem mutatkozik jelentős eltérés a két oldal között.

\section{AZ ÉRVELÉSEK NYILVÁNOSSÁGA}

2015 elején az Országgyưlés elfogadta a paksi beruházással kapcsolatos vállalkozói szerződések, múszaki specifikációk, a magyar-orosz megállapodás részletei és az előkészítő hatástanulmány harminc évre szóló titkosítását. A paksi titoktörvénynek nevezett intézkedés ellen politikai pártok és civil szervezetek fogtak akcióba, és jogi úton próbálták feloldatni a dokumentáció titkosítását. Az adatok korlátozását illetően az infotörvényre ${ }^{19}$ hivatkoztak, amely kimondja a közérdekú adatokhoz való hozzáférés korlátozhatóságát nemzetbiztonsági okból vagy üzleti érdekből. A dokumentáció egy része bírósági pereskedéseket követően 2019-ben vált nyilvánossá. A deliberáció szakirodalma szerint a döntés legitimitásának egyik feltétele a döntést megalapozó érvelés nyilvánossága. Az érvek elérhetősége ugyanis hozzájárul az egyének informálódásához, tudásuk gazdagításához a döntés tárgyát képező közügyet illetôen (Gutmann-Thompson, 2004), aminek következtében bővül az argumentatív repertoárjuk (Cappella-Price-Nir, 2002), azaz a döntési opciók mellett és ellen felhozható érvek ismerete.

A kormány érvelésében a politikai viták szükségességéhez hasonlóan kettősség figyelhető meg: egyszerre hivatkoznak üzleti titokra és müszaki adatokra a paksi szerződések hozzáférhetetlensége kapcsán, és állítják, hogy ennek ellenére a projekt átlátható. A dokumentáció titkosítása, valamint a bírósági ítéletek ellenére azok hiányos rendelkezésre bocsátása a felelősségre vonhatóság elkerülését mutatja, így depolitizációs kísérletként értelmezhető. Ezzel szemben az LMP az elmaradt tenderrel kapcsolatos érveléséhez hasonlóan a jogi aggályokra hívja fel a figyelmet (amellett, hogy jogi intézkedéseket is tesz az ügyben). Arra apellálnak, hogy az üzleti titkot felülírja a több ezer milliárdos beruházás megismerhetőségének követelménye közérdekű adat okán. Az állampolgárok hozzáférésére hivatkoznak, hiszen enélkül nem képesek megalapozottan véleményt formálni és döntést hozni Paks 2 kérdésében, ugyanis a társadalom nem zárható ki a deliberációból. Az LMP érvelése tehát politizációra enged következtetni. Az érvelések nyilvánossága - mint a döntés legitimitásának kritériuma - kapcsán elemzett érvek a jog témakörébe sorolhatók, 
azon belül is az infotörvény hatásköre értelmében a Magyarországon hatályos törvények betartásához. A kormány tehát amellett érvel, hogy a projekt nem törvénysértő, az LMP viszont ezt cáfolja. Ahogy a 2. ábra mutatja, a magyar jogsértést illetően az LMP sokkal aktívabb érvelési tevékenységet végez, mint a kormány.

2. táblázat. Érvek az átláthatóságról

\section{Kormány}

[...] a Paks II-törvény 5. §-a az adatfajták konkrét meghatározásával, az infotörvényben meghatározott speciális célok közül a nemzetbiztonsági érdekre, illetve a szellemi tulajdonhoz füződő jogra tekintettel rendeli el a közérdekû adatok megismerésének korlátozását. A törvény kizárólag a szerződéses adatok tekintetében, azon belül is két adatfajta, üzleti és múszaki adatok körében engedi meg az információhoz való hozzáférésnek az infotörvény alapján történő korlátozását, azaz közérdekû adatként történő megismerése kikényszeríthetőségének korlátozását. ${ }^{20}$

[...] a teljes eljárás ideje alatt az információk elérhetőek voltak a hatóságként eljáró kormányhivatal, a Földmúvelésügyi Minisztérium és a Paks II projekttársaság honlapján elektronikusan. ${ }^{22}$

[...] az atomerőmű beruházásnál kevés átláthatóbb beruházása volt a magyar államnak. $^{24}$

\section{LMP}

[...] a kormány indoklás nélkül megtagadta ezeknek a hatástanulmányoknak és kockázatbecsléseknek az átadását, ezért a közérdekú adatigénylés megtagadása miatt pert indítanak a nap folyamán - tette hozzá, megjegyezve, nemcsak a műszaki, környezeti, hanem energiagazdaságossági tanulmányokra is. ${ }^{21}$

[...] az LMP szerint egy sok ezermilliárdos állami beruházásnál nincs helye a titkolózásnak: adatigénylési pert indítunk, hogy a magyar állampolgárok tisztában lehessenek vele, mennyit kell még fizetniük - a bővítési projekt költségein túl - az Orbánkormány nukleáris láz(ár)álmáért. ${ }^{23}$

[...] vissza kell lépni a bővítéstől, hiszen körülötte továbbra is teljes a titkolózás. ${ }^{25}$

\section{A TÁRSADALOM RÉSZVÉTELE}

Az Espooi Egyezmény előírja az atomerőmúvek bővítésével kapcsolatosan közmeghallgatások lefolytatását. 2015 márciusától kezdve a paksi régióban és külföldön a kormány több közmeghallgatást és lakossági fórumot tartott, amelyeken az érdeklődőknek lehetőséget adtak véleményük kifejtésére és aggá- 
lyaik megfogalmazására. A kormány és az LMP közötti nézeteltérés abban áll, hogy az LMP ezeket a deliberatív rendezvényeket nem tartja a társadalom megfelelő mértékú bevonásának, arra hivatkozva, hogy a nem Paks közelében élőknek nincs módjuk részt venni az eseményeken, pedig ők is érintettek a döntés által. Már a magyar-orosz megállapodást megelőző években is népszavazást szorgalmaztak a kérdésről, hiszen csak így lenne módja a társadalom minden tagjának a döntéshozatalban való részvételre. A Greenpeace által megrendelt reprezentatív közvélemény-kutatások eredményei azt mutatják, hogy a lakosság többsége elutasítja a bővítést, azaz az LMP a többségi szavazatra apellálva szándékozik semmissé tenni a Paks 2-ről szóló döntést. A népszavazás részben jogi kérdés, ugyanis Magyarország Alaptörvénye előírja, milyen kérdésekben szükséges vagy tilos népszavazást kiírni. Fontos megjegyezni, hogy például Ausztriában, Olaszországban és Svájcban tartottak népszavazást a nukleáris energiatermelésről, tehát a referendum lehetősége az egyes országoktól és a projektek körülményeitől függ. Ugyanakkor tanulmányomban az érvek tartalma okán a társadalom részvételére a döntéshozatalban, illetve a bővítés társadalom általi támogatottságára etikai és nem jogi kérdésként tekintek.

3. táblázat. Érvek a társadalom részvételéről és támogatásáról

\section{Kormány}

[...] a környezetvédelmi eljárásnak köszönhetően a hazai és külföldi nyilvánosság megismerhette a tervezett nukleáris projektet, az eljárással példaértékú precedenst állított Magyarország a nemzetközi közösség számára a környezeti döntéshozatal során a nyilvánossági jogok széleskörü gyakorlásának biztosítására. ${ }^{26}$

[...] a miniszter szerint olyan ügyről van szó, amiről a nép már szavazott a 2014-es választáson. ${ }^{28}$

[...] a népszavazási kezdeményezés politikai akció, az nem az atomerőmúről szól..$^{30}$

[...] a 40 környékbeli település fórumain pedig az derült ki, hogy a helyi közösségek elsöprő arányban támogatják a bővítést. ${ }^{32}$

\section{LMP}

[...] az atomfüggőség, az eladósodás és az Orbán-Putyin-Mangold-lobbi ellen a magyar emberek csakis az LMP által kezdeményezett népszavazással vehetik fel a harcot. ${ }^{27}$ (n) 
A kormány érvelése, miszerint a közmeghallgatások és a lakossági fórumok sikerrel lezajlottak, nem tekinthető depolitizációs kísérletnek. Az az érv azonban, amely a népszavazást arra hivatkozva utasítja el, hogy a társadalom már kinyilvánította véleményét Paks 2-rôl a 2014-es parlamenti választásokon keresztül, depolitizációként értelmezhető. Ezt az érvet az LMP meg is cáfolja. Egy pártra szavazás ugyanis nem jelenti azt, hogy az állampolgárok a párt minden döntésével egyetértenének. A népszavazás gondolata szintén politikai színezetet kap, mivel a kormány az LMP hatalomra törési kísérletét látja a kezdeményezésekben, az LMP szerint pedig a kormány saját hatalmi játékát próbálja védeni a referendum megakadályozásával. A 2. ábra mutatja, hogy az LMP online cikkeiben több mint háromszor olyan gyakran került azonosításra érv a társadalmi részvétel hiányát illetően, mint a kormánynál, akik megfelelőnek ítélik a döntés által érintettek megnyilatkozását.

A deliberáció és a döntés abban az esetben tekinthető legitimnek, amenynyiben a döntés által érintetteknek lehetőségük volt a véleménynyilvánításra, amely alapján a döntést meghozzák. A deliberáció, illetve az azon alapuló deliberatív demokrácia ellentmondása abban áll, hogy lehetetlen a döntés által érintett összes személy részvétele, következésképpen nem is születhetnek legitim politikai döntések. Ráadásul azt is szinte lehetetlen megválaszolni, hogy kiket érint egy-egy döntés (Parkinson, 2006). Ugyanakkor Paks 2 esetében éveken keresztül vita tárgyát képezi, hogy a társadalom mekkora része és milyen formában döntsön, illetve dönthet a projektről.

\section{KONKLÚZIÓ}

A 2014-es megállapodások sorozata Magyarország és az Orosz Föderáció között a paksi atomerőmú bővítéséről nemcsak egy újabb vitatott eseménye lett a politikai, média- és közéleti diskurzusoknak, hanem egyúttal meg is változtatta, miről szól a paksi bővítés deliberációja. Ugyanis már nem az volt a kérdés, hogy a magyar energetika jövőjében szerepet kap-e a nukleáris energia, hanem az, hogy az atomenergia további felhasználása orosz állami hitelből és kivitelezők által fog-e bekövetkezni. Jelen írásban amellett érveltem, hogy a 2014. januári kormányközi egyezmény a paksi bővítés vitájának egy olyan megosztó pontjává vált, hogy a kormánynál mint a kitüntetett hatalmi pozícióban lévő állami szervnél a kérdés depolitizációja volt megfigyelhető, szemben a politizációt mutató, gyengébb hatalmi pozíciókban lévő ellenzéki zöld párttal.

A Paks 2-ről szóló döntés legitimitása több szempontból is megkérdőjeleződött, amelyek közül tanulmányomban a következőkre fókuszáltam: a döntést nem egy szúk csoport hozza meg (Dryzek, 1996), az érvelések nyilvánosak (Parkinson, 2006), a döntés az érintettek véleménynyilvánítása után és bele- 
egyezése alapján születik (Dryzek, 2001; Bohman, 1996; Sanders, 1997). A kormány érvelése leggyakrabban a nemzetközi jog betartásáról szólt, pontosabban a tender elmaradásának Európai Bizottsági elfogadását említették. Ez nem meglepő, hiszen ellentétben a közbeszerzési eljárás elmaradásának jogi felülvizsgálatával, a paksi szerződések titkosítását követően a dokumentáció nyilvánosságáért folytatott bírósági eljárások a kormány adatszolgáltatásával zárultak. Éppen ezért az LMP a Magyarországon hatályos jogszabályokkal kapcsolatban érvelt gyakrabban és a perek végül az ő javukra dőltek el. Az LMP emellett kiemelt figyelmet szentelt a társadalom döntéshozatalból való kihagyásának, amellyel politizálni próbálta a Paks 2-rôl szóló deliberációt. Az ellenzéki párt politizációjával szemben a kormány érvelésében depolitizációs kísérleteket azonosítottam.

Fontos megjegyezni, hogy a döntés legitimitása nem kizárólag az ellenzéki politikai pártok és politikusok által vitatott, hanem szakértők, az energiaszektor vállalati szereplői és egyéb politikai tisztségeket betöltők által is. Az Energiaklub Szakpolitikai Intézet atomenergia-specialistája, Perger András az egész folyamat legitimitását kérdőjelezte meg, visszautalva a 2009-es országgyúlési határozatra. ${ }^{34}$ Mártha Imre, az MVM-csoport volt vezérigazgatója a magyar-orosz megállapodásról azt nyilatkozta, hogy az "finoman szólva is egy kávé mellett dólt el". ${ }^{55}$ Sólyom László, volt köztársasági elnök pedig a következőt nyilatkozta a Magyar Tudományos Akadémia egyik konferenciáján: „Ami azonban a Miniszterelnökségre korlátozott titkos elókészitésból, az elegendó információ nélkül az Országgyúlésre hárított döntésböl, az alig néhány képviselö jelenlétében lefolyt ún. vitából, s végül az érdemi adatok tíz évre való titkositásából kibontakozik, az nem más, mint a hatalomgyakorlás hitelességi válsága". ${ }^{36}$

\section{JEGYZETEK}

${ }^{1}$ A Greenpeace Magyarország első atomenergiával kapcsolatos közvélemény-kutatását 2012-ben rendelte meg. Ezek után 2014-ben két felmérést, 2016-ban és 2017-ben egyet-egyet rendelt meg, amelyekben a következő kérdés szerepelt: „Egyetért-e Ön a paksi atomerőmú bővítésével, amennyiben azt egy orosz állami vállalat, orosz hitelből építi meg?" A magyarországi atomenergiával és Paks 2-vel kapcsolatos közvélemény-kutatásokról részletesebben: Strategic maneuvering in extended polylogues (Egres Dorottya, megjelenés alatt).

${ }^{2}$ Paks II titkai, 2014. december 10. https://energiaklub.hu/hirek/paks-ii-titkai-3680, Paks II-fórum a Stádium 28 kör szervezésében, https://www.youtube.com/watch?v=2gi8wYsCQfY

3 A kormány honlapján kizárólag a 2014 utáni cikkek voltak elérhetők, többek között ez indokolja, hogy jelen tanulmányban kizárólag a Paks 2 vita 2014 utáni szakaszára fókuszáljak. Továbbá az elemzés részét képezte a Magyar Tudományos Akadémia honlapjának vizsgálata.

${ }^{4}$ http://www.kormany.hu/hu/hirek és http://lehetmas.hu/hirek/ 
${ }^{5}$ A szakmai viták adekvátságáról, valamint a jövő generációkról szóló érvekkel ebben az írásban nem foglalkozom, ezzel magyarázható az 1. ábrán jelzett jog és etika témaköröknél feltüntetett összegek és a 2. ábrán jelzett két témakörön belüli érvek összegének eltérése.

${ }^{6}$ Az atomerőmü-építés a megvalósítás szakaszába lép, 2017. április 13. https://wwww.kormany.hu/ hu/miniszterelnokseg/hirek/az-atomeromu-epites-a-megvalositas-szakaszaba-lep

7 A kormány le akarja „tolni az Országgyưlés torkán” a paksi bővítésről szóló szerződést, 2014. január 30.

8 Jelentős előrelépést vár a paksi beruházás ügyében Lázár János, 2016. május 25. https://www. kormany.hu/hu/miniszterelnokseg/hirek/jelentos-elorelepest-var-a-paksi-beruhazas-ugyeben-lazar-janos

9 Az LMP panaszt tesz az ombudsmannál „kormányzati visszásságok” miatt, 2014. január 28.

${ }^{10}$ A paksi beruházás átláthatósága megfelel az európai normáknak, 2015. március 4. https://www. kormany.hu/hu/a-miniszterelnok/hirek/a-paksi-beruhazas-atlathatosaga-megfelel-az-euro pai-normaknak

11 Vállalja a vitát a paksi bővítés ügyében a kormány! 2015. március 9.

12 Nem közeledünk Oroszországhoz, 2014. november 24. https://www.kormany.hu/hu/a-miniszterelnok/hirek/nem-kozeledunk-oroszorszaghoz

${ }^{13}$ Az LMP feljelentést tesz a legújabb paksi kommunikációs tender miatt, 2014. április 18.

${ }^{14}$ Megnyílt a budapesti Atomex Europe konferencia és kiállítás, 2015. november 30. https://www. kormany.hu/hu/hirek/megnyilt-a-budapesti-atomex-europe-konferencia-es-kiallitas

${ }^{15}$ Nemzetközi szerződést sért az erőmű bővítése, 2014. február 22.

${ }^{16}$ Két engedélyt is megkaphat Paks II. tavasszal, 2017. március 1. https://www.kormany.hu/hu/ hirek/ket-engedelyt-is-megkaphat-paks-ii-tavasszal

${ }_{17}$ Paks: állítsanak le minden előkészületet!, 2015. november 19.

${ }_{18}$ 25/2009. (IV. 2.) OGY határozat az atomenergiáról szóló 1996. évi CXVI. törvény 7. §-ának (2) bekezdése alapján, a paksi atomerőmú telephelyén új atomerőmúvi blokk(ok) létesítésének előkészítését szolgáló tevékenység megkezdéséhez szükséges előzetes, elvi hozzájárulás megadásáról.

19 2011. évi CXII. törvény az információs önrendelkezési jogról és az információszabadságról.

${ }^{20}$ Völner Pál expozéja a Paks II.-törvény módosításáról, 2016. március 18. https://www.kormany. hu/hu/igazsagugyi-miniszterium/parlamenti-allamtitkarsag/beszedek-publikaciok-interjuk/ volner-pal-expozeja-a-paks-ii-torveny-modositasarol

${ }^{21}$ Az LMP pert indít a kormány ellen a hatástanulmányokért, 2014. február 6.

${ }_{22}$ Megkapta a környezetvédelmi engedélyt a paksi bővítés, 2016. szeptember 29. https://www. kormany.hu/hu/miniszterelnokseg/hirek/megkapta-a-kornyezetvedelmi-engedelyt-a-paksibovites

${ }^{23}$ Az LMP kipereli az atomtemető eltitkolt adatait, 2015. június 9.

${ }^{24}$ A kormány fenntartja a tömeges bevándorlás okozta válsághelyzetet, 2017. március 2. https:// www.kormany.hu/hu/miniszterelnokseg/hirek/a-kormany-fenntartja-a-tomeges-bevandorlas-okozta-valsaghelyzetet

${ }^{25}$ LMP: nem a titkolózásra, nem a moszkvai megállapodásokra! 2014. április 11. 
${ }^{26}$ Megkapta a környezetvédelmi engedélyt a paksi bővítés, 2016. szeptember 29. https://www. kormany.hu/hu/miniszterelnokseg/hirek/megkapta-a-kornyezetvedelmi-engedelyt-a-paksibovites

${ }^{27}$ Csatát nyert az atomlobbi Brüsszelben - sokáig azért ne örüljenek! 2017. március 5.

${ }^{28}$ A kormány fenntartja a tömeges bevándorlás okozta válsághelyzetet, 2017. március 2. https:// www.kormany.hu/hu/miniszterelnokseg/hirek/a-kormany-fenntartja-a-tomeges-bevandorlas-okozta-valsaghelyzetet

${ }^{29}$ Jancsó Andrea: a kormány Brüsszelbe is exportálta a korrupciót, 2017. március 19.

${ }^{30}$ A kormány fenntartja a tömeges bevándorlás okozta válsághelyzetet, 2017. március 2. https:// www.kormany.hu/hu/miniszterelnokseg/hirek/a-kormany-fenntartja-a-tomeges-bevandorlas-okozta-valsaghelyzetet

${ }^{31}$ Csatát nyert az atomlobbi Brüsszelben - sokáig azért ne örüljenek! 2017. március 5.

${ }^{32}$ Kormányinfó 81-60 évre rendeződik az ország áramigénye, 2017. március 9. https://www.kormany. hu/hu/miniszterelnokseg/videok/kormanyinfo-81-60-evre-rendezodik-az-orszag-aramigenye

${ }^{33}$ Fel kell mondani a paksi szerződést! 2015. február 17.

${ }^{34}$ Kovács Áron, Szabó M. István: Paks II.: Gyurcsány pálfordulásától Orbán nagy üzletéig, 2014. január 15. https://hvg.hu/gazdasag/20140115_Oroszok_Pakson__hogyan_jutottunk_idaig

${ }^{35}$ Paks II. - az évszázad üzlete, de kinek? Ökopódium, Budapest, 2017. 11. 15. https://www.youtube. $\mathrm{com} /$ watch? $\mathrm{v}=6 \mathrm{zOX} 40 \mathrm{eTs} 4 \mathrm{U} \&$ list=LL-klOG1pFXk57RENOV9jjIA\&index=93\&t=0s 1:30:061:30:10.

${ }^{36}$ Sólyom a Fidesz hitelességi válságáról beszélt, 2014. február 18. https://index.hu/belfold/2014/ 02/18/solyom_amit_tudnunk_kene_paksrol_az_titkos/

\section{IRODALOM}

Antal Attila (2016): A közjó és a civilek. In: Antal Attila (szerk.): A civilek hatalma. A politikai tér visszafoglalása. Budapest, Noran Libro, 47-60. ISBN: 978-615-56-6728-2.

Arisztotelész (1997): Nikomakhoszi Etika. Fordította Szabó Miklós. Budapest, Európa Kiadó. ISBN: 963-07-6160-2.

Bates, Steven-Jenkins, Laura-Amery, Fran (2014): (De)Politicisation and the Father's Clause Parliamentary Debates. Policy and Politics, Vol. 42, No. 2, 243-258. https://doi.org/10.1332/ $030557312 \times 656007$

Bessette, Joseph M. (1994): The Mild Voice of Reason: Deliberative Democracy and American National Government. Chicago, University of Chicago Press. ISBN: 9780226044248.

Bohman, James (1996): Public Deliberation. Pluralism, Complexity, and Democracy. Cambridge, The MIT Press. ISBN: 9780262024105.

Bond, Sophie-Diprose, Gradon-Thomas, Amanda C. (2019): Contesting deep sea oil: Politicisation- depoliticisation-repoliticisation. EPC: Politics and Space, Vol. 37, No. 3, 519-538. https:// doi.org/10.1177/2399654418788675 
Boniolo, Giovanni-Schiavone, Giuseppe (2015): Deliberation and Democracy. In: Neil J. SmelserPaul B. Baltes (eds.): International Encyclopedia of the Social \& Behavioral Sciences, Second edition, Vol. 6, 61-67. http://dx.doi.org/10.1016/B978-0-08-097086-8.93030-7

Burnham, Peter (2001): New Labour and the Politics of Depoliticisation. British Journal of Politics and International Relations, Vol. 3, No. 2, 127-149. https://doi.org/10.1111/1467-856X.00054

Cappella, Joseph N.-Price, Vincent-Nir, Lilach (2002): Argument repertoire as a reliable and valid measure of opinion quality: Electronic dialogue during campaign 2000. Political Communication, Vol. 19, No. 1, 73-93. https://doi.org/10.1080/105846002317246498

Chailleux, Sébastien (2020): Making the subsurface political: How enhanced oil recovery techniques reshaped the energy transition. EPC: Politics and Space, Vol. 38, No. 4, 1-18. https://doi.org/ 10.1177/2399654419884077

Cohen, Joshua (1989): Deliberation and democratic legitimacy. In: Alan Hamlin-Philip Pettit (eds.): The good polity: Normative analysis of the state. Cambridge, Basil Blackwell, 17-34. ISBN: 9780-631-15804-2.

Delli Carpini, Michael X.-Lomax Cook, Fay-Jacobs, Lawrence R. (2004): Public Deliberation, Discursive Participation, and Citizen Engagement: A Review of the Empirical Literature. Annual Review of Political Science, Vol. 7, 315-344. https://doi.org/10.1146/annurev.polisci.7.121003. 091630

Dryzek, John S. (1996): Political Inclusion and the Dynamics of Democratization. The American Political Science Review, Vol. 90, No. 3, 475-487. https://doi.org/10.2307/2082603

Dryzek, John S. (2001): Legitimacy and economy in deliberative democracy. Political Theory, Vol. 29, No. 5, 651-669. https://doi.org/10.1177/0090591701029005003

Egres Dorottya (megjelenés alatt): Strategic maneuvering in extended polylogues. Journal of Argumentation in Context.

Egres Dorottya-Petschner Anna (2020): The Paks Pact: Topoi in Hungarian Nuclear Energy Discourse. In: Jens Allwood-Olga Pombo-Clara Renna-Giovanni Scarafile (eds.): Controversies and Interdisciplinarity. Beyond disciplinary fragmentation for a new knowledge model. Amsterdam, John Benjamins Publishing Company, 29-52. https://doi.org/10.1075/cvs.16.02egr

Elster, Jon (1998): Deliberative Democracy. Cambridge, Cambridge University Press. https://doi. org/10.1017/CBO9781139175005

Fisher, B. Aubrey-Ellis, Donald G. (1993): Small Group Decision Making: Communication and the Group Process, Fourth edition. New York, McGraw-Hill. ISBN: 9780070212121.

Fishkin, James S. (1997): The Voice of the People: Public Opinion and Democracy, Second edition. New Haven, Connecticut, Yale University Press. ISBN: 9780300065565.

Flinders, Matthew-Buller, Jim (2006): Depoliticisation: Principles, Tactics and Tools. British Politics, Vol. 1, No. 3, 293-318. https://doi.org/10.1057/palgrave.bp.4200016

Foster, Emma Ann-Kerr, Peter-Byrne, Cristopher (2014): Rolling Back to Roll Forward: Depoliticisation and the Extension of Government. Policy and Politics, Vol. 42, No. 2, 225-241. https:// doi.org/10.1332/030557312X655945

Goodin, Robert E. (2000): Democratic Deliberation Within. Philosophy and Public Affairs, Vol. 29, No. 1, 81-109. https://doi.org/10.1111/j.1088-4963.2000.00081.x 
Gutmann, Amy-Thompson, Dennis (1996): Democracy and Disagreement: Why Moral Conflict Cannot be Avoided in Politics, and What Should be Done About it. Cambridge, Belknap Press. ISBN: 9780300065565.

Gutmann, Amy-Thompson, Dennis (2004): Why Deliberative Democracy. Princeton, Princeton University Press. ISBN: 9780691120195 . www.jstor.org/stable/j.ctt7t5w5

Jenkins, Laura (2011): The Difference Genealogy Makes: Strategies for Politicisation or How to Extend Capacities for Autonomy. Political Studies, Vol. 59, No. 1, 156-174. https://doi.org/10. 1111/j.1467-9248.2010.00844.x

Joss, Simon-Durant, John (1995): Public Participation in Science: The Role of Consensus Conferences in Europe. London, Science Museum. ISBN: 978-0901805850.

Kettell, Steven (2008): Does Depoliticization Work? Evidence from Britain's Membership of the Exchange Rate Mechanism, 1990-1992. British Journal of Politics and International Relations, Vol. 10, No. 4, 630-648. https://doi.org/10.1111/j.1467-856X.2008.00338.x

Kuzemko, Caroline (2015): Energy Depoliticisation in the UK: Destroying Political Capacity. The British Journal of Politics and International Relations, Vol. 18, No. 1, 107-124. https://doi.org/10. 1111/1467-856X.12068

Lewiński, Marcin-Mohammed, Dima (2013): Argumentation in Political Deliberation. Journal of Argumentation in Context, Vol. 2, No. 1, 1-9. https://doi.org/10.1075/jaic.2.1.00int

Manin, Bernard-Stein, Elly-Mansbridge, Jane (1987): On Legitimacy and Political Deliberation. Political Theory, Vol. 15, No. 3, 338-368. https://doi.org/10.1177/0090591787015003005

Mansbridge, Jane (1999): Everyday Talk in the Deliberative System. In: Stephen Macedo (ed.): Deliberative Politics: Essays on 'Democracy and Disagreement. New York, Oxford University Press, 221-239. ISBN: 978-0-691-04478-1.

Mansbridge, Jane (2010): Everyday Talk Goes Viral. Paper Presented at Annual Meeting of The American Political Science Association, Washington.

Myers, C. Daniel-Mendelberg, Tali (2013): Political Deliberation. In: Leonie Huddy-David O. Sears-Jack S. Levy (eds.): The Oxford Handbook of Political Psychology, Second edition. New York, Oxford University Press. https://doi.org/10.1093/oxfordhb/9780199760107.013.0022

Parkinson, John (2001): Deliberative Democracy and Referendums. In: Keith M. Dowding-Jim Hughes-Helen Margetts (eds.): Challenges to Democracy: Ideas, Involvement and Institutions. London, Palgrave, 131-152. https://doi.org/10.1057/9780230502185

Parkinson, John (2006): Deliberating in the Real World. Problems of Legitimacy in Deliberative Democracy. New York, Oxford University Press. https://doi.org/10.1093/019929111X.001.0001

Polleri, Maxime (2019): Post-political uncertainties: Governing nuclear controversies in post-Fukushima Japan. Social Studies of Science, Vol. 0, No. 0, 1-22. https://doi.org/10.1177/030631 2719889405

Sanders, Lynn M. (1997): Against Deliberation. Political Theory, Vol. 25, No. 3, 347-376. https://doi. org/10.1177/0090591797025003002

Smith, Graham- Corinne Wales (1999): Citizenship and Locality: The Theory and Practice of Citizens' Juries'. Policy and Politics, Vol. 27, No. 3, 295-308. https://doi.org/10.1332/030557399782 453118 
Stewart, John-Kendall, Elizabeth-Coote, Anna (1994): Citizens' Juries. London, Institute for Public Policy Research. ISBN: 9781872452951.

Strange, Gerard (2014): Depoliticisation, the Management of Money and the Renewal of Social Democracy: New Labour's Keynesianism and the Political Economy of 'Discretionary Constraint'. New Political Economy, Vol. 19, No. 1, 138-154. https://doi.org/10.1080/13563467. 2013.779648

Szabó Gabriella-Bene Márton (2016): Széttöredezett vagy összekapcsolódó? A magyar médianyilvánosság hálózatszerkezete három eset tükrében. Politikatudományi Szemle, Vol. 25, No. 3, 33-58. http://www.poltudszemle.hu/szamok/2016_3szam/szabo_bene.pdf

Tafon, Ralph-Howarth, David-Griggs, Steven (2019): The Politics of Estonia's Offshore Wind Energy Programme: Discourse, Power and Marine Spatial Planning. Environment and Planning C: Politics and Space, Vol. 37, No. 1, 157-176. https://doi.org/10.1177/2399654418778037

van Eemeren, Frans H. (2010): Strategic Maneuvering in Argumentative Discourse, Extending the Pragma-dialectical Theory of Argumentation. Amsterdam, John Benjamins. https://doi.org/10. 1075/aic.2

van Eemeren, Frans. H. (2018): Argumentation theory: A pragma-dialectical perspective. Springer. https://doi.org/10.1007/978-3-319-95381-6

van Eemeren, Frans H.-Houtlosser, Peter (2002): Strategic maneuvering with the burden of proof. In: Frans H. van Eemeren (ed.): Advances in pragma-dialectics. Amsterdam: Sic Sat, 13-28. ISBN: 90-74049-06-0.

Vépy-Schlemmer Éva Rita (2015): A deliberáció hatása. A kaposvári deliberatív közvélemény-kutatás tapasztalatai. Doktori Értekezés. Budapesti Corvinus Egyetem Szociológia Doktori Iskola. https://doi.org/10.14267/phd.2016046

Walton, Douglas N. (1998): The New Dialectic: Conversational Contexts of Argument. Toronto, University of Toronto Press. ISBN: 978-0802079879.

Walton, Douglas-Krabbe, Erik C. W. (1995): Commitment in Dialogue. Albany, New York, State University of New York Press. ISBN: 978-0791425862.

Wood, Matt (2016): Politicisation, Depoliticisation and Anti-Politics: Towards a Multilevel Research Agenda. Political Studies Review. Vol. 14, No. 4, 521-533. https://doi.org/10.1111/1478-9302.12074

Wood, Matt-Flinders, Matthew (2014): Rethinking Depoliticisation: Beyond the Governmental. Policy and Politics, Vol. 42, No. 2, 151-170. https://doi.org/10.1332/030557312X655909

Ylönen, Marja-Litmanen, Tapio-Kojo, Matti-Lindell, Pirita (2017): The (De)Politicisation of Nuclear Power: The Finnish Discussion after Fukushima. Public Understanding of Science, Vol. 26, No. 3, 260-274. https://doi.org/10.1177/0963662515613678 